\title{
STUDENTS' PERCEPTION TOWARD THE IMPLEMENTATION OF DIGITAL STORYTELLING IN TEACHING WRITING
}

\author{
${ }^{1)}$ Yanuarti Apsari, ${ }^{2)}$ Intan Satriani \\ 1)yanuar.apsaril@gmail.com, ${ }^{2}$ intan.satriani@yahoo.co.id
}

${ }^{1,2)}$ STKIP SILIWANGI BANDUNG

\begin{abstract}
ABSTRAK
Makalah ini melaporkan penelitian persepsi siswa tentang pelaksanaan bercerita digital dalam pengajaran menulis untuk siswa semester II STKIP Siliwangi Bandung. Penelitian ini bertujuan untuk mengetahui manfaat dan tantangan dari menggunakan cerita digital. Penelitian ini muncul karena era digitalisasi menjawab. Dimana, siswa harus diakomodasi oleh teknologi dalam proses belajar mengajar. Penelitian ini dilakukan di STKIP Siliwangi Bandung. Subjek penelitian ini menulis untuk siswa komunikasi umum. Data diperoleh dari wawancara siswa. Temuan mengungkapkan bahwa ada beberapa manfaat. Mereka adalah pengembangan kemampuan siswa menulis, peningkatan siswa membaca pemahaman, pengembangan siswa keterampilan kerjasama, peningkatan siswa partisipasi di kelas, suasana menyenangkan belajar dan meningkatnya minat menulis siswa. Tantangan itu ada hubungannya dengan kemampuan siswa. Berdasarkan temuan tersebut, disarankan untuk memperoleh data dalam penelitian dan memodifikasi praktek mengajar baru.
\end{abstract}

Kata Kunci : Persepsi siswa; Mendongeng digital; Pengajaran Menulis

\begin{abstract}
This paper reports a research of students' perception on the implementation of digital storytelling in teaching writing to second semester students of STKIP Siliwangi Bandung. The research aims to find out the benefits and challenges of using digital storytelling. This research comes up due to answering digitalization era. Wherein, students should be accommodated by technology in teaching learning process. The research was conducted at STKIP Siliwangi Bandung. The subject of this research was writing for general communication students. The data were obtained from students' interview. The findings revealed that there are some benefits. They are the development of students' writing ability, the improvement of students' reading comprehension, the development of students' cooperation skill, the increasing of students' participation in the class, fun learning's atmosphere and the increasing of students' writing interest. The challenges had something to do with students' proficiency. Based on those findings, it is suggested to obtain deep data of the research and to modify new teaching practice.
\end{abstract}

Keywords: Students' Perception; Digital Storytelling; Teaching Writing

\section{Introduction}

Nowadays students can easily acquire and share the information or their stories to others through technology (computer, software, websites, internet, blog, podcast, you tube, facebook, and wikis) (Mishan, 2005; Dudeney \& Hockly, 2007; Frazel, 2010, p.11). Technology can give learners exposure to practice all four language skills, make them to be significantly active in teaching learning process. It also creates students to be independent learners since they experience the activities in joyful and interesting way by themselves (Wright, 2001; Dudeney \& Hockly, 2007; Suherdi, 2012).

Those are needed by the teachers to accommodate technology in teaching and learning process
(Suherdi, 2012, p.72). In accommodating technology based learning for students, Frazel (2010, p. 9) and Yuksel et al (n.d) suggest digital storytelling as a process that blends media or digital devices to enrich the written or spoken word and to support the educational process. Digital storytelling is a modern expression of storytelling which presents digital technology and instructional resources to tell the story with many topics (Digital Storytelling Association, 2002; Ohler, 2008; Frazel, 2010, p.8). Moreover, when teacher utilizes digital storytelling as a teaching technique, students can dig their unique creativity and expression, reach a wider audience, develop skill in internet content, do research, and write for different audiences and topics (Sharp, 2009, p. 231; Frazel, 2010, p.7). 
However, this study which focuses on finding out students' perception on the implementation of digital storytelling in teaching writing. This study also observes students' reaction towards the transdisciplinary research between English teaching and ICT. Rising up transdisciplinary research of digital storytelling in teaching writing seems to be crucial in showing the different way of teaching writing to students which blend more than one media in teaching activities. Hence, this study finds out the benefits and shortcomings of the use of digital storytelling in teaching writing.

\section{Review of Literature}

\subsection{Overview Digital Storytelling}

Storytelling is defined as an ancient art or natural method which uses the story images drawn on cave walls and brings human communication and social interaction about one self, others, or the world (McDrury \& Alterio, 2003; Frazel, 2010, p.1). In using storytelling, educators can encourage learners to tell stories from their complex ideas, concepts, or information which they had experienced and linked it to the world and own stories (McDrury\&Alterio, 2003, p. 34; Chung, 2006). Through stories, learners are able to share about themselves, families, friends and colleagues, communities, environments, cultures, and place in history (Wright, 2008). The stories can be real or fictitious. Those depend on what kind of text which will be taught by teachers.

Nowadays, with the rapid development of technology, Joe Lambert and the late Dana Atchley helped the Center of Digital Storytelling to create the digital storytelling movement as a new version of storytelling (Center for Digital Storytelling, 2005; Robin, 2008, p.222). Digital storytelling is defined as a new educational tool (Lunce, n.d, p. 77) which integrates between computer technology and multimedia elements with storytelling or teaching and learning (Frazel, 2010, p.1; Xu, et al., 2011, p.181).

The innovation of digital storytelling is seen from tools needed for that process such as computers, scanners, digital cameras, high quality digital audio capture devices, and multimedia narratives (Meadows, 2003; Robin, 2008, p.222). Robin adds that those devices have become increasingly more affordable and accessible (2008, p.222). Through computer generated text and multimedia content, digital storytelling brings new life from the ancient craft of written or oral storytelling (Frazel, 2010, p.1) to the students.
Digital storytelling is also known as the modern expression of the ancient art of storytelling which is utilized to share knowledge, wisdom, and values through the computer and other supported media (Center for Digital Storytelling, 2005; DeNatale, 2008, p.2). McCulloch (cited in Frazel, 2010, p. 15) mentions digital storytelling as an embedded innovative practice among educationalists in all sectors in Australia. Teachers in primary, secondary, community, and tertiary institutions have accepted this powerful media (Chase, 2010; Frazel, 2010, p. 15) for a wide range of purposes in teaching and learning, especially in improving students' writing skill (Krismiyati, 2013, p. 4).

Digital storytelling in an educational setting allows students and educators to enhance their information gathering and problem solving skills (Robin, 2009 in Yuksel, n.d), facilitate students' ability to work collaboratively in team (McDrury\&Alterio, 2003; Frazel, 2010, p. 9), allow them to construct their own meaning through personally meaningful writing (Robin, 2008, p. 223), and allow users to create a social community around the stories (Frazel, 2010, p. 9).

\subsection{The Importance of Digital Storytelling related to Writing}

Teachers should consider the positive and negative sides of the media for both teachers and students, when applying a teaching media in the classroom. In integrating technology and storytelling through digital storytelling, there are five benefits for both teachers and students. Firstly, digital storytelling provides students with opportunities to apply emerging technologies as part of their learning (Porter, 2008, p.7) and develop a range of digital communication styles in a knowledge society (Frazel, 2010, pp.2-3).

Secondly, digital storytelling gives spaces for the students to be active learners in the process of teaching and learning through reflecting, representing, and communicating what they know (Cennamo, et al., 2010, p.91; Frazel, 2010, p.11). Thirdly, digital storytelling creates fun and excitement learning's atmosphere where students are involved to create a short movie that presents a compelling personal perspective (Cennamo, et al., 2010, p.91; Frazel, 2010, p.11).

The Fourth benefit of digital storytelling, it is an effective media for both visual and auditory learners to demonstrate to them the complexity of project management and the importance of 
audience (Frazel, 2010, p.11). Finally, digital storytelling can develop students' skills in analyzing internet content (Sharp, 2009, p. 231; Frazel, 2010, p.11), doing research in different topics (Sharp, 2009, p. 231), and writing content collaboratively for different audiences (Sharp, 2009, p. 231; Frazel, 2010, pp.2-3).

\section{Methodology}

In investigating such research, this method has objective based on a research question. This research was conducted to describe and explore students' perspective in implementing the technique.

The data of this study were obtained from students' interview. Semi structured interview was used to collect in-depth responses from the respondents and to set clear limits of questions in avoiding wider students' responses (Patton, 1990 in O'Donoghue and Punch, 2003, p.21; Heigham and Croker, 2009, p.187).

\section{Finding and Discussion}

With regard to the second research question, this subchapter presents the benefits that appeared in the implementation of digital storytelling in teaching writing for the second semester students of university level. However, this research also found some challenges in the implementation of teaching program. The benefits and challenges that were found in this research will be depicted in the following sections.

\subsubsection{Benefits of the Implementation of Digital Storytelling in Teaching Writing}

This study found six benefits from the implementation of digital storytelling in teaching writing. The benefits attained the development of students' writing ability, the improvement of students' reading comprehension, the development of students' cooperation skill, the increasing of students' participation in the class, fun learning's atmosphere and the increasing of students' writing interest. The aforementioned benefits are described below.

\subsubsection{Students Developed Their Writing Ability}

Based on the data of students' interview, it was found that students developed their writing ability. The development of writing ability in this research can be seen in the following except:
After practicing to write digital storytelling regularly I can express my idea easily and develop my ideas in writing easier.

(S5) (Interview, translated version)

The above excerpt showed that when teacher utilizes digital storytelling as a teaching technique, students can dig their unique creativity and expression, reach a wider audience, develop skill in internet content, do research, and write for different audiences and topics (Sharp, 2009, p. 231; Frazel, 2010, p.7). This means that linking writing to reading text can be an effective method of generating ideas and aiding writing process (Baker and Boonkit, 2004).

Related to the development of students' writing ability, student one perceived that after learning narrative using storytelling, she was able to make a good story, as can be seen in the excerpt below.

Through creating digital storytelling I learned more about grammatical rules. My understanding in grammar also developed. Then, I got a lot of vocabularies from the activity.

(S1) (Interview, translated version)

The findings above also showed that digital storytelling can improve students' writing skill (Krismiyati, 2013, p.4).

\subsubsection{Students Improved Their Reading Comprehension}

Besides the development in writing ability, students also got an improvement in reading. The result of interview about reading development can be seen in the following excerpt.

Through writing digital storytelling made us understand the text better because before writing we need to read the text for many times. We can understand the story.

(S2) (Interview, translated version)

From the above interview, the students perceived that they liked reading using digital storytelling because they could easily comprehend the material of the story. This finding showed that writing activities can be useful for improving reading comprehension (Stotsky, 1983) by allowing ESL readers to articulate their understanding of and connection to a text (Petrosky, 1982). 


\subsubsection{Students Improved Their Skill of Cooperation}

In creating digital storytelling, the students need to complete the task in a team. They got the result of learning through the cooperation with other students that all students in the groups benefit from the interactive experience (Kessler, 1992), as can be seen in the excerpt below.

In creating digital storytelling, we worked in a group. So, we need to work together and share our ideas with our friends and discuss about what we are going to write. Sometimes, we got difficulty when we had different ideas in completing the task.

(S2) (Interview, translated version)

The above excerpt showed that digital storytelling can facilitate students' ability to work collaboratively in team (McDrury \& Alterio, 2003; Frazel 2010, p.9). This means that in learning community, students can enhance broader skills of cooperation (Harmer, 2001). Thus, through digital storytelling students can improve both academic and social skills.

\subsubsection{Digital Storytelling Increased the Amount of Students' Participation}

The implementation of digital storytelling is in accordance with the characteristic of cooperative learning in which focuses on learner centered. The students are actively involved in the teaching and learning process. It is supported by interview result of student five below.

Digital storytelling makes students to be significantly active in teaching and learning process because everyone in a group has a role. It is started by deciding the topic story, finding the design, editing until uploading the video in facebook. I enjoyed doing every stages. Because it is the new experience for us, every group tried to create the good result.

(S5) (Interview, translated version)

The findings above showed that digital storytelling gave space for students to be the active learners in the process of teaching and learning through reflecting, representing and communicating what they know (Cennamo, et al,. 2010, p.91; Frazel 2010, p.11).

\subsubsection{Digital Storytelling Created Fun Learning's Atmosphere}

All respondents said that they enjoyed writing digital story telling. It is relevant with the statement of Cennamo, et al. (2010, p.91) and Frazel (2010, p.11) that digital storytelling creates fun and excitement learning's atmosphere where students are involved to create a short movie that presents a compelling personal perspective. It is supported by interview result of student three below.

It is a new experience for us to create digital storytelling. I am happy to write it because we can write the story by using computer. In writing class, the teacher always asked us to write in a paper.

(S3) (Interview, translated version)

This finding showed that digital storytelling provided students with opportunities to apply emerging technologies as part of their learning (Porter, 2008, p.7). This made students to be independent learner since they experience the activities in joyful and interesting way by themselves (Wright, 2001; Dudeney \& Hockly, 2007; Suherdi 2012). Thus, it is suggested for the teachers to accommodate technology in teaching and learning process (Suherdi, 2012, p.72).

\subsubsection{Students were Motivated to Write}

After creating digital storytelling, the students were motivated to write better, as stated by student four below.

Before participating in writing digital storytelling I was confused to start writing. I thought that writing activity is boring because the teacher always asks us to write in a piece of paper. But, after I knew digital storytelling I was interested to write by using various media.

(S4) (Interview, translated version)

The findings above showed that digital storytelling as one way to increase students' engagement to respond writing activity, especially for students who did not respond the traditional academic writing assignments (DeNatale, 2008, p.2). Therefore, this technique has been found to be an effective means of arousing interest in writing. 


\subsubsection{Challenge of the Implementation of Digital Storytelling in Teaching Writing}

The challenge was obtained in this research mainly deals with the students' English proficiency. All students admitted that the lack of language proficiency such as vocabularies, grammar, and pronunciation was their obstacle in implementing the teaching program. This problem found out that students still lack of vocabularies. Consequently, it made students hard in expressing their opinions, as stated by student two below.

I had difficulty in setting the appropriate grammar. I don't know what I had written grammatically correct or not.

\section{(S2) (Interview, translated version)}

The above excerpt in line with Cohen (1994, pp. 328-329 in Saehu, 2008, p. 26), who stated that many writers do not have good control on structure. This might be caused by their lack of reading various kinds of text. As stated by Harmer (2007, p.99) that students need to read lots of references since reading texts provide good models for English writing concerning construction of phrases, sentences, paragraph, and whole texts.

In addition, the students also had the problem with finding the appropriate words. It is supported by interview result of student five below.

The most difficult stage in creating digital storytelling for me is when we have to compose the story. Because I realize that my vocabulary mastery is very limited. So, I did many mistakes when I translated the story into English related to the choice of word. Fortunately, the teacher always helps us to correct it.

(S5) (Interview, translated version)

The data of interview above showed that by having many stocks of words, the students could express their ideas and write some kinds of topic easily. Since there was a high correlation between those who read a lot and those who improved their vocabulary acquisition when they read. Thus, the students need to read a lot to increase their vocabulary mastery.

The findings above are relevant with Cohen (1994, pp. 328-329 in Saehu, 2008, p.26) that the difficulty in writing can be caused by students' weaknesses to master the components of writing itself, for example lack of vocabulary, choices of words, and word forms.

\section{Conclusion and Recommendation}

Based on data of students' interview, the gained data indicated that although there were some restrictions, the incorporation of digital storytelling to the teaching program had assisted students to develop their writing skill. This research revealed that the teaching program spawned six benefits from the implementation of digital storytelling in teaching writing. The benefits attained the development of students' writing ability, the improvement of students' reading comprehension, the development of students' cooperation skill, the increasing of students' participation in the class, fun learning's atmosphere and the increasing of students' writing interest. Nevertheless, the attainment of those benefits might be constrained by some challenges found in this teaching program. The challenges had something to do with students' proficiency.

As aforementioned statement, it can be concluded that the result of the research confirmed possibility of the teaching program which incorporates digital storytelling in supporting university level students to have good awareness in expressing their ideas. Furthermore, the use of media can facilitate and help students to develop their writing ability, which is highly required in facing globalization era especially $\mathrm{Z}$ generation.

\section{REFERENCES}

Cennamo, K. S., Ross, J. D. \& Ertmer, P. A. (2010). Technology integration for meaningful classroom use: A standardsbased approach. CA: Wadsworth.

Center for Digital Storytelling. (2005). Center for digital storytelling website. [Online]. Available at: http://www. storycenter.org/history.html. Retrieved on May 17, 2014.

Chase, J. E. (2010). Digital storytelling for success. CA: Professional Media Group.

Chung, S. K. (2006). Digital storytelling in integrated arts education. The International Journal of Arts Education, 4 (1), pp. 3350.

DeNatale, M.G. (2008). Digital storytelling: Tips and resources. Boston: Simmons College.

Digital Storytelling Association. (2002). The center for digital storytelling. [Online] 
Available at: http://www.dsaweb.org. Accessed on May, 17, 2014.

Dudeney, G. \& Hockly, N. (2007). How to teach English with technology. Essex: Pearson Education Limited.

Frazel, M. (2010). Digital storytelling guide for educators. Washington, DC: International Society for Technology in Education (ISTE).

Heigham, J. \& Croker, A. R. (2009). Qualitative research in applied linguistics. New York: Palgrave Macmillan.

Krismiyati. (2013). Bringing technology into the classroom through digital storytelling. Asia Pacific Collaborative Education Journal, 9 (2), pp. 1-10.

Lunce, C. (n.d.). Digital storytelling as an educational tool. Indiana Libraries, 30 (1), pp. 77-80.

McDrury, J. \& Alterio, M. (2003). Learning through storytelling in higher education: using reflection and experience to improve learning. London: Kogan Page Limited.

Meadows, D. (2003). Digital storytelling: Research based practice in new media. Visual Communication, 2 (2), pp. 189-193.

Mishan, F. (2005). Designing authenticity into language learning materials. [Online] Available in: http://sv.libarts.psu.ac.th/. Retrieved on May 17, 2014.

O’Donoghue, A. T.\& Punch, F. K. (2003). Qualitative educational research in action: Doing and reflecting. London: Routledge Falmer.

Ohler, J. (2008). Digital storytelling in the classroom. California: Corwin Press.

Porter, B. (2008). Digital storytelling. [Online]. Available in: http://www.DigitTales.us. Retrieved on May 10, 2014.

Robin, B. R. (2008). Digital storytelling: A powerful technology tool for the $21^{\text {st }}$ century classroom. Theory into Practice, 47, pp. 220-228.

Sharp, V. F. (2009). Computer education for teachers: Integrating technology into classroom teaching (6 $\left.6^{\text {th }} E d.\right)$. NJ: John Wiley \& Sons, Inc.

Suherdi, D. (2012). Towards $21^{\text {st }}$ century english teacher education: An Indonesian perspective. Bandung: CELTICS Press.

Wright, A. (2001). Art and crafts with children: Resource books for teachers. Oxford: Oxford University Press.

Wright, A. (2008). Storytelling with children. Oxford: Oxford University Press.
Xu, Y., Park, H. \& Baek, Y. (2011). A new approach toward digital storytelling: An activity focused on writing self-efficacy in a virtual learning environment. Educational Technology and Society, 14 (4), pp. 181-191.

Yuksel, P., Robin, R.B. \& McNeil, S. (n.d.). Educational uses of digital storytelling around the world. [Online] Available at: digitalstorytelling.coe.uh.edu/.../SITE. 